\title{
HYDROGRAPHICAL MODELLING FOR POTENTIALITY OF WATER HARVESTING AND LAND/USE PLANNING, WADI EL ATFEHY, EASTERN DESERT, EGYPT
}

\author{
Morsy, S. M. ${ }^{1}$ and Abdel Monaim N. A. ${ }^{2}$ \\ 1 Faculty of Science, Ain Shams University, Cairo, Egypt \\ 2 National Authority for remote Sensing and Planetary Sciences
}

\begin{abstract}
Runoff Water Harvesting (RWH) is an effective solution to overcome scarcity of water in arid regions. The target of this study is to identify the suitable sites for (RWH) constructions and to determine the high potential zones for water/Landuse. The present study concerned with El Atfehy hydrographic basin as one of the most promising regions in the Eastern desert of Egypt due to its economic importance related to the demand for alternative water resources. The present work provides the integration of (GIS); satellite images $(\mathrm{ETM}+)$ and watershed modeling system (WMS) as a new approach for sustainable development of water resources. Based on these techniques the most effective hydrologic and hydromorphometric criteria that represent effective impact factors were integrated and analyzed in a GIS framework to develop Weighted Spatial Probability Model (WSPM). An appropriate weightage was specified to each criteria according to its impact on water potentiality. The resulting RWH potentiality map delineates the study area into five classes from very low to very high runoff potentiality. Water/Landuse master plan is constructed to recognize the priority regions for agricultural and socio-economic activities. The resulting map reveals that about $18 \%$ of the total hydrographic basin area is the most promising regions for water/Landuse. Application of the integrated methodology introduces a new approach for water resources management in the selected basin and allover the arid regions.
\end{abstract}

Keywords: GIS, RS, Modelling, RWH, Land/Use planning, Water Resources Management.

\section{INTRODUCTION}

Despite of its arid desert climate; Eastern Desert of Egypt sometimes receives occasional storms with heavy showers (Korany; 1980, Saleh; 1990, Faiad 1996 and NWRC 2003). Torrential floods have are recorded through five or three years of recurrence period during the last few years (Morsy, 2016). Due to presence of high plateaux and slopes in El Atfehy hydrographic basin, the occasional heavy showers during the winter season were recorded which represent the possible routes for the seasonal contribution feeding the water budget, either on the surface or in subsurface (Korany, 1980). Abdel Moneam, 2016, recorded five flash storms and flood events at 1987, 1991, 1994, 1996, and 1997 in the study area. Accordingly, the rainwater must be husbanded and water/Landuse must be properly managed in this area. The aim of this study is to develop a modeling for estimation of water potential of surface water and groundwater resources of aquifer systems in a selected basin, through Weighted Spatial Probability Model (WSPM), using GIS and RS satellite images. Several geological and geomorphological studies have been carried out on the study area among them are; Said 1962, 1971 and 1990, Mansour et al. 1982, Korany 1995, El Ghazawi et al; 2001, Moneim; 2005, El Maghraby et al; 2014). Bapalu and Sinha (2005) evaluated El Atfehy hydrographic sub-basin flash flood hazardous degree. Weighted Spatial Probability Modelling (WSPM) was applied by Malczewski (1996) and Malczewski (2006) to determine the runoff water harvesting $(\mathrm{RWH})$ potentialities either for groundwater recharge or land reclamation. 


\section{STUDY AREA}

El -Atfehy hydrographic basin occupies an area of about $425 \mathrm{Km}^{2}$ north the Eastern Desert of Egypt. (Fig. 1). It is mainly developed through the Eocene carbonate rocks. Upper and Middle Eocene rock units are exposed on the surface and covered by Quaternary deposits within the main channel, tributaries, and the delta (Said, 1990 and Korany, 1995). Figure (2) is a geologic map of the study basin.

The Quaternary and Eocene aquifer systems are defined by previous works in El-Atfehy hydrographic basin. The Quaternary aquifer occupies the downstream and delta parts. It is built of unconsolidated gravels, sands and clay intercalations. The Middle Eocene aquifer occupying the upstream and mid-stream areas, built of limestone and chalky limestone water bearing rocks. The aquifers are mainly recharged by rainfall during the occasional storms, lateral inflow from the connected aquifers in the neighboring basins and in the Nile Valley (Korany, 1995 and Korany et al. 1997).

The Quaternary and Eocene aquifer systems are defined by previous works in El-Atfehy hydrographic basin. The Quaternary aquifer occupies the downstream and delta parts. It is built of unconsolidated gravels, sands and clay intercalations. The Middle Eocene aquifer occupying the upstream and mid-stream areas, built of limestone and chalky limestone water bearing rocks. The aquifers are mainly recharged by rainfall during the occasional storms, lateral inflow from the connected aquifers in the neighboring basins and in the Nile Valley (Korany, 1995 and Korany et al. 1997).

Fig. Location map of the area
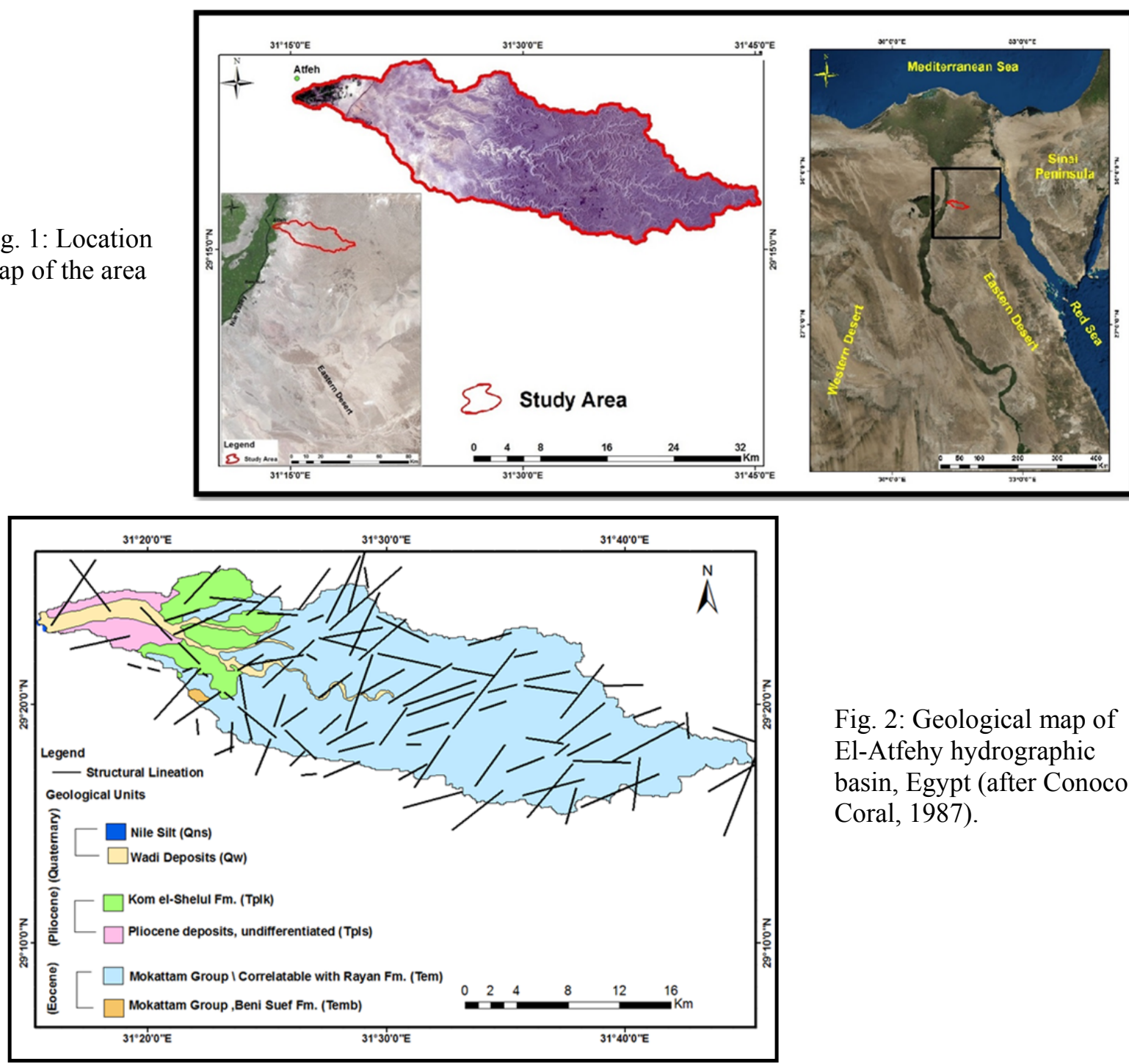

Fig. 2: Geological map of El-Atfehy hydrographic basin, Egypt (after Conoco, Coral, 1987). 
Hydrographical modelling for potentiality of water harvesting

\section{MATERIALS}

I. Enhanced Thematic Mapper Plus (ETM+) landsat satellite images (Earth Explorer), (GIS) (ESRI), Aster DEM of $30 \mathrm{~m}$ resolution on (ASTER GEDM), Watershed Modeling System (WMS 8.4 @ Aquaveo), Conoco geological map and hydrogeological map (RIGW and NWRC, 1999)

II. Data obtained by analysis of the drainage network of El-Atfehy hydrographic basin (Morsy, 2016), using the following units:

A- ASTER DEM 30m (Fig. 3)

III. B- Landsat satellite image ETM+ 8 for the study area (Fig.4); formed from combination of bands $(6,5,4)$ resolution $15 \mathrm{~m}$. showing the distribution of different geomorphologic features as cultivated land, flat area and Wadis.

Fig. 3: ASTER

DEM 30m image
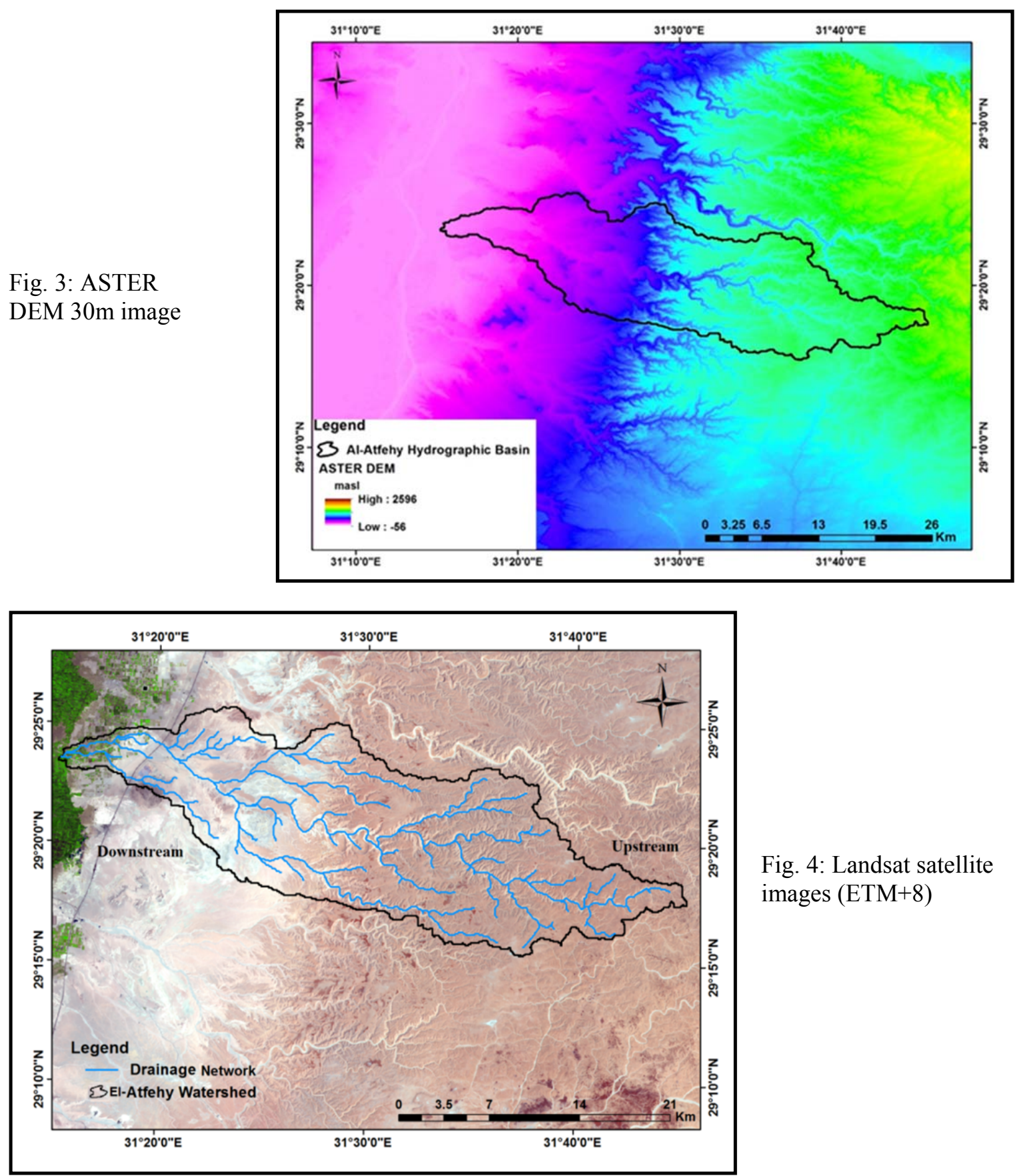

Fig. 4: Landsat satellite images $(\mathrm{ETM}+8)$ 
IV. ArcGIS 10.1@software, Erdas Imagine 2013@ software (Intergraph), and WMS 8.4@ (Watershed Modeling System). Quantification of surface runoff rates from rainfall intensities using the HEC-1, Flood Modelling (SCS).

V. Mapping of Suitability of Geological Units from Conoco, Coral, 1987 geological map sheet (1: 500,000); (Fig. 2)

Mapping of Groundwater Prospective Units (GPU) from the hydrogeological map of Egypt $(1: 2,000,000)$ (RIGW and NWRC, 1999); (Fig. 5)

Fig. 5: Hydrogeological units of the study area (after RIGW and NWRC, 1999)

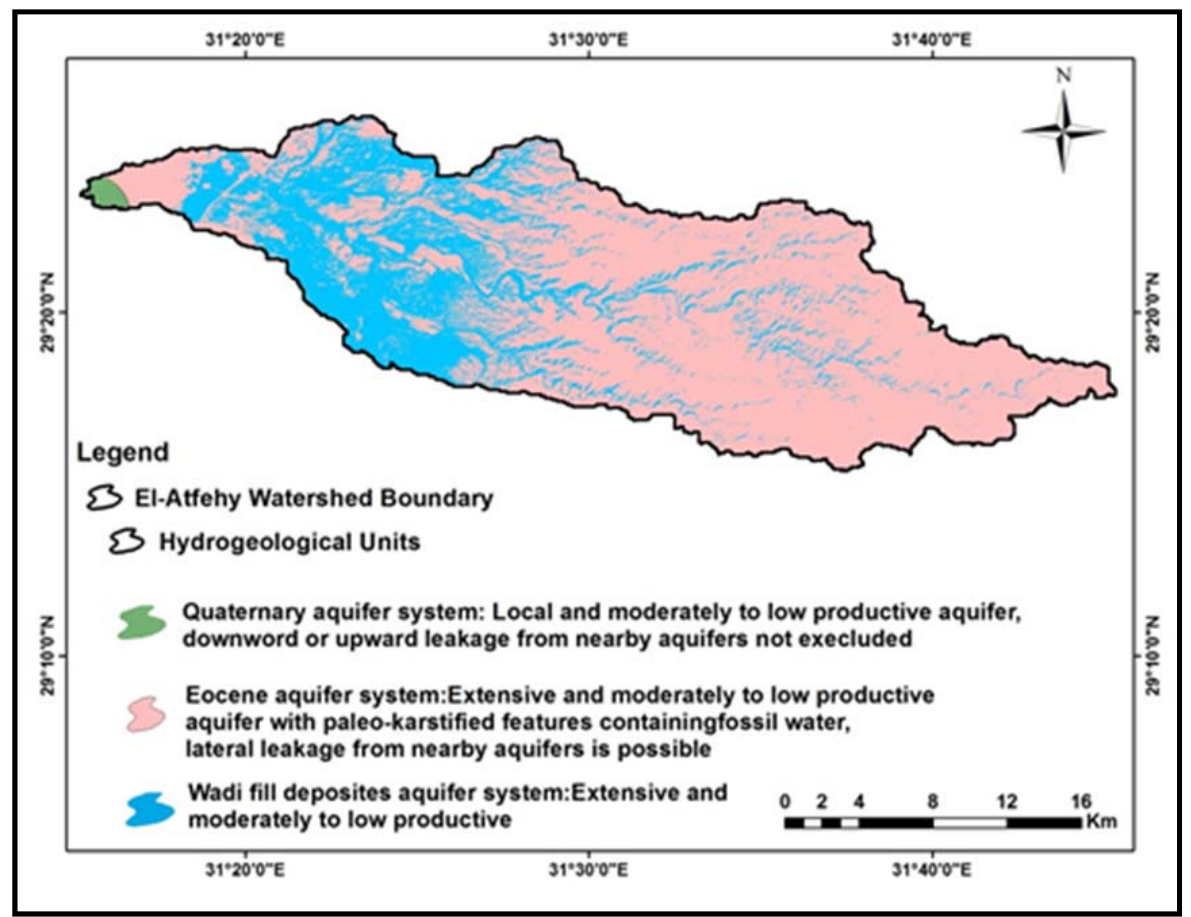

\section{METHODS}

Applying of Weighted Spatial Probability Modelling (WSPM) provided by Malczewski 1996 and Malczewski 2006; to determine the (RWH) potentialities either for groundwater recharge or land reclamation and to construct Water/Land use Master Plan potentiality mapping. Where after defining basins attributes with the DEM inside the platform of WMS 8.4C software; multi criteria decision support layers that represent the most effective hydrologic and hydromorphometric impact factors were integrated and analyzed in a GIS framework to develop Weighted Spatial Probability Model (WSPM); the ranges of these input layers used in the (WSPM) are given in Tables (1), (2) and (3).

\section{RESULTS and DISCUSSION}

\section{Construction of multi criteria decision support layers}

The (WSPM) is applied by an integration of multi criteria decision support of layers that represent the most effective hydrologic and hydromorphometric impacts in the basins attributes. The multi-criteria decision support systems (MCDSS) are provided by Malczewski 1996, Malczewski 2006, Elewa and Qaddah 2012 and Elewa et al. 2013.They are the following layers:

\section{Runoff Volume (VRF)}

The runoff volume is calculated by using watershed-modelling system (WMS 8.4) via SCS Curve Number Method (Soil Conservation Service 1972 and 1975) (Fig. 6). This method is developed by the USDA (United States Department of Agriculture, 1986) which was formerly called the Soil Conservation Service or SCS- it is still known as a "SCS runoff curve number". References, such as from 
Hydrographical modelling for potentiality of water harvesting

USDA indicate the runoff curve numbers for characteristic land cover descriptions and a hydrologic soil group. The runoff equation is:

$$
Q= \begin{cases}0 & \text { for } P \leq I_{a} \\ \frac{\left(P-I_{a}\right)^{2}}{P-I_{a}+S} & \text { for } P>I_{a}\end{cases}
$$

$\mathrm{Q}$ is Accumulated direct runoff (inch or $\mathrm{mm}$ )

$\mathrm{P}$ is Accumulated rainfall (potential maximum runoff) (inch or $\mathrm{mm}$ )

$\mathrm{S}$ is Potential maximum retention (inch or $\mathrm{mm}$ )

Ia $=$ Initial Losses (in. or mm).

$$
S=z\left(\frac{100}{R C N}-1\right)
$$

$\mathrm{Z}$ is 10 for English units or 254 for metric units. And Ia $=0.2 S$ has a range from 30 to 100 .

Runoff Curve Number (RCN) for dry

$$
\mathrm{RCN}(\mathrm{I})=\frac{4.2 \mathrm{RCN}(\mathrm{II})}{10-0.058 \mathrm{RCN}(\mathrm{II})}
$$

\begin{tabular}{|c|c|c|c|c|c|}
\hline RWH Criteria & Very high & High & Moderate & Low & Very Low \\
\hline $\begin{array}{c}\begin{array}{c}\text { Volume of Runoff } \\
\left(\mathrm{m}^{3}\right)\end{array} \\
.\end{array}$ & $>80,195.1$ & $58,235.6-80,195.0$ & $37,567.9-58,235.6$ & $22,497.7$ - $37,567.9$ & $<22,497.74$ \\
\hline $\begin{array}{l}\text { Overland Flow } \\
\text { Distance }(\mathrm{km})\end{array}$ & $>0.22836$ & $0.21389-0.22835$ & $0.19589-0.21388$ & $0.17594-0.19588$ & $<0.1759$ \\
\hline $\begin{array}{c}\text { Maximum Flow } \\
\text { Distance }(\mathrm{m}) \\
\end{array}$ & $>33.595$ & $24.62-33.594$ & $16.829-24.619$ & $10.394-16.828$ & $<10.393$ \\
\hline $\begin{array}{c}\text { Basin infiltration } \\
\text { number }\end{array}$ & $>18.433$ & $16.289-18.432$ & $13.944-16.288$ & $12.084-13.943$ & $<12.083$ \\
\hline $\begin{array}{c}\text { Drainage Density } \\
\left(\mathrm{km}^{-1}\right)\end{array}$ & $>3.0545$ & $2.8179-3.0544$ & $2.5445-2.8178$ & $2.3185-2.5444$ & $<2.318$ \\
\hline Basin Area $\left(\mathrm{km}^{2}\right)$ & $>63.056$ & $45.599-63.055$ & $27.811-45.598$ & $14.636-27.810$ & $<14.63$ \\
\hline Basin Slope $(\mathrm{m} / \mathrm{m})$ & $>0.12564$ & $0.099239-0.12563$ & $\begin{array}{c}0.07093-0.09923 \\
\end{array}$ & $\begin{array}{c}0.04454-0.07092 \\
\end{array}$ & $<0.0445$ \\
\hline Basin Length $(\mathrm{km})$ & $>26.986$ & $19.49-26.985$ & $13.125-19.489$ & $7.7496-13.124$ & $<7.749$ \\
\hline
\end{tabular}

Table1: Ranges of input criteria used in (WSPM) for El-Atfehy hydrographic basin

Table 2: WMS 8.4@ software hydrographical output criteria used for demarcating the hydrographic basin's characteristics of El-Atfehy for water/land use potentiality mapping

\begin{tabular}{|c|c|c|c|c|c|}
\hline Basin ID & Sub-basin & Basin Slope $(\mathrm{m} / \mathrm{m})$ & Basin ID & Sub-basin & Basin Slope $(\mathrm{m} / \mathrm{m})$ \\
\hline 1 & Umm Shieha & 0.015839 & 9 & Al Jibu & 0.149369 \\
\hline 2 & UmmJinays & 0.054063 & 10 & Sub-basin 3 & 0.030476 \\
\hline 3 & Abu Mighayir & 0.094696 & 11 & Sub-basin 2 & 0.034114 \\
\hline 4 & Umm Ratamah & 0.094887 & 12 & Umm Roussa & 0.131572 \\
\hline 5 & Sub-basin 1 & 0.053884 & 13 & Umm Sayalah & 0.150122 \\
\hline 6 & Homary & 0.033806 & 14 & Al Jarariyyah & 0.101055 \\
\hline 7 & Abu Mesally & 0.037204 & 15 & Al Hutilyyah & 0.095569 \\
\hline 8 & Al Asliyyah & 0.067514 & 16 & Mean Channel & 0.146422 \\
\hline
\end{tabular}

\begin{tabular}{|c|c|c|c|c|c|}
\hline $\begin{array}{l}\text { Hydrographic basin } \\
\text { Model Criterion }\end{array}$ & Very high & High & Moderate & Low & Very Low \\
\hline VRF (m3) & $>22,497.74$ & $22,497.7-37,567.9$ & $37,567.9-58,235.6$ & $\begin{array}{c}58,235.6-80,195.0 \\
\end{array}$ & $<<80,195.1$ \\
\hline $\mathrm{BS}(\mathrm{m} / \mathrm{m})$ & $>0.12564$ & $0.099239-0.12563$ & $0.07093-0.09923$ & $0.04454-0.07092$ & $<0.0445$ \\
\hline SGU & $\mathrm{A}$ & $\mathrm{B}$ & $\mathrm{C}$ & $\mathrm{D}$ & ---- \\
\hline GPU & "---- & $\mathrm{A}$ & $\mathrm{B}$ & $\mathrm{C}$ & "---- \\
\hline
\end{tabular}

Table 3: Ranges of input criteria used in the WSPM for water/and use potentiality mapping of El-Atfehy hydrographic basin 


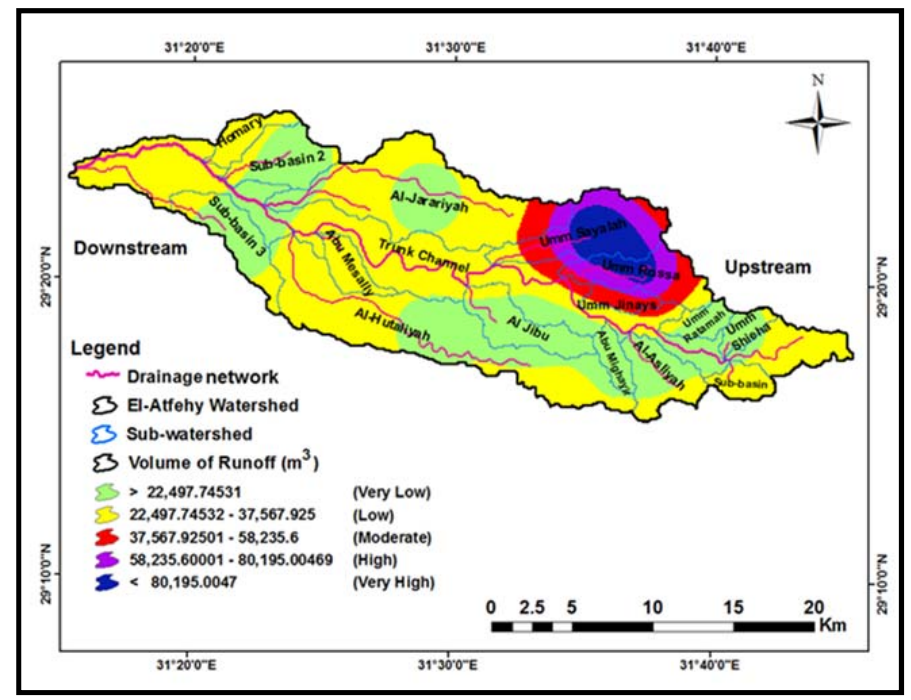

Fig. 6: The thematic layer of the Volume of Runoff (VRF) of El-Atfehy hydrographic basin

\section{Average Overland Flow Distance (OFD)}

OFD within a hydrographic basin is computed by averaging the overland flow distance traveled from the centroid of each triangle to the nearest stream. The OFD is affected by the soil type and topography that govern the rates of erosion caused by the overland flow (Montgomery and Dietrich, 1989). Rainfall is called surface runoff when reaches the channels.

$$
\mathrm{OFD}=1 / 2 \mathrm{Dd}
$$

Dd is the drainage density of the basin $\left(\mathrm{Km}^{-1}\right)$ (Fig. 7).

\section{Basin Slope (BS)}

The BS is important in determining both infiltration capability and the resulting runoff and plays a very strong role in determining rainwater deceleration, acceleration or infiltration (Subba Rao, 2006). It is the average slope of the triangles comprising this basin (Horton, 1945; Leopold and Maddock, 1953). Whereas, the BS decreases in the western downstream parts $(<0.04454 \mathrm{~m} / \mathrm{m})$, which doubles the possibilities of the RWH (Fig. 8).

\section{Drainage density (Dd)}

The Dd is a measure for the degree of fluvial dissection and is influenced by numerous factors, among them; the erosion resistance of rocks, the land infiltration capacity, basin slope and climate conditions (Verstappen, 1983). The higher the Dd the higher is the RWH potential, and vice versa, where high values of Dd produce more runoff comparable to others (Aher et al., 2014). The Dd is introduced by Horton 1932 as the total length of stream segments of all orders per unit area (Fig. 9).

$$
\mathrm{Dd}=\sum \mathrm{Lu} / \mathrm{Au}
$$

Where: $\mathrm{Au}$ is basin area $\left(\mathrm{Km}^{2}\right)$ and $\mathrm{Lu}$ is the total stream length $(\mathrm{Km})$.

\section{Basin Length (BL)}

The BL is defined as the distance which cut the basin into two similar parts (Horton, 1945). The longer the BL the lower the chances that such a basin will be flooded; or in other words the longer the basin the lower its slope and hence the higher the possibilities for the RWH, as viewed in larger sub-basins of ElAtfehy hydrographic basin. (Fig. 10). 
Hydrographical modelling for potentiality of water harvesting

Fig. 7: The thematic layer of the Average OFD of El-Atfehy hydrographic basin
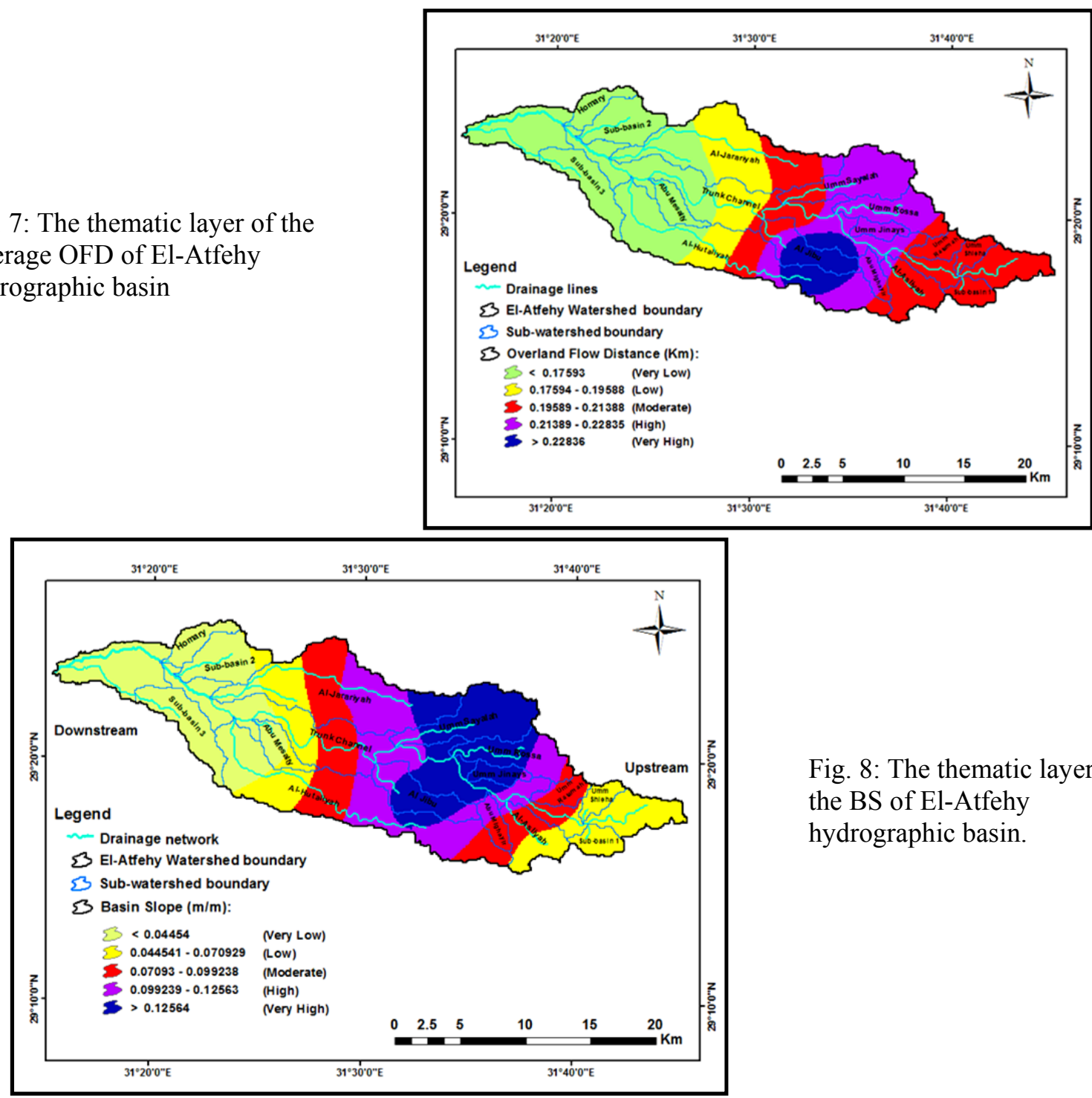

Fig. 8: The thematic layer of the BS of El-Atfehy hydrographic basin.

Fig. 9: The thematic layer of the Dd of ElAtfehy hydrographic basin.

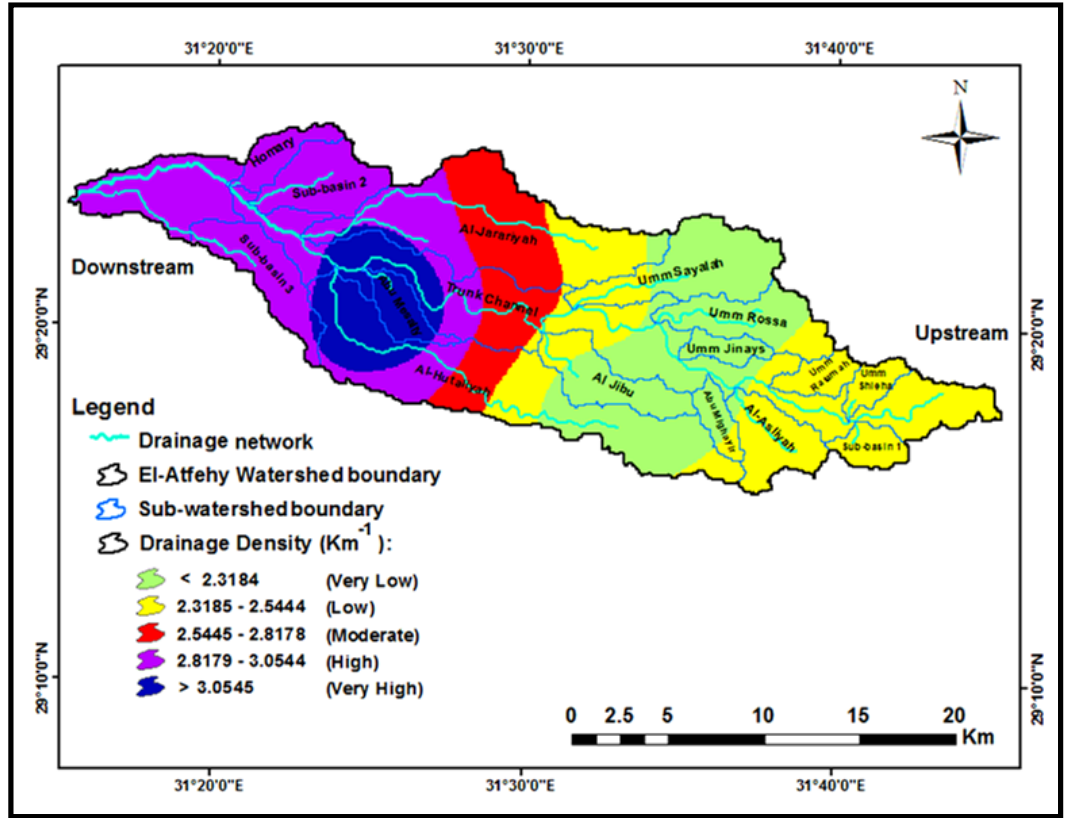


Morsy, S. M. and Abdel Monaim N. A

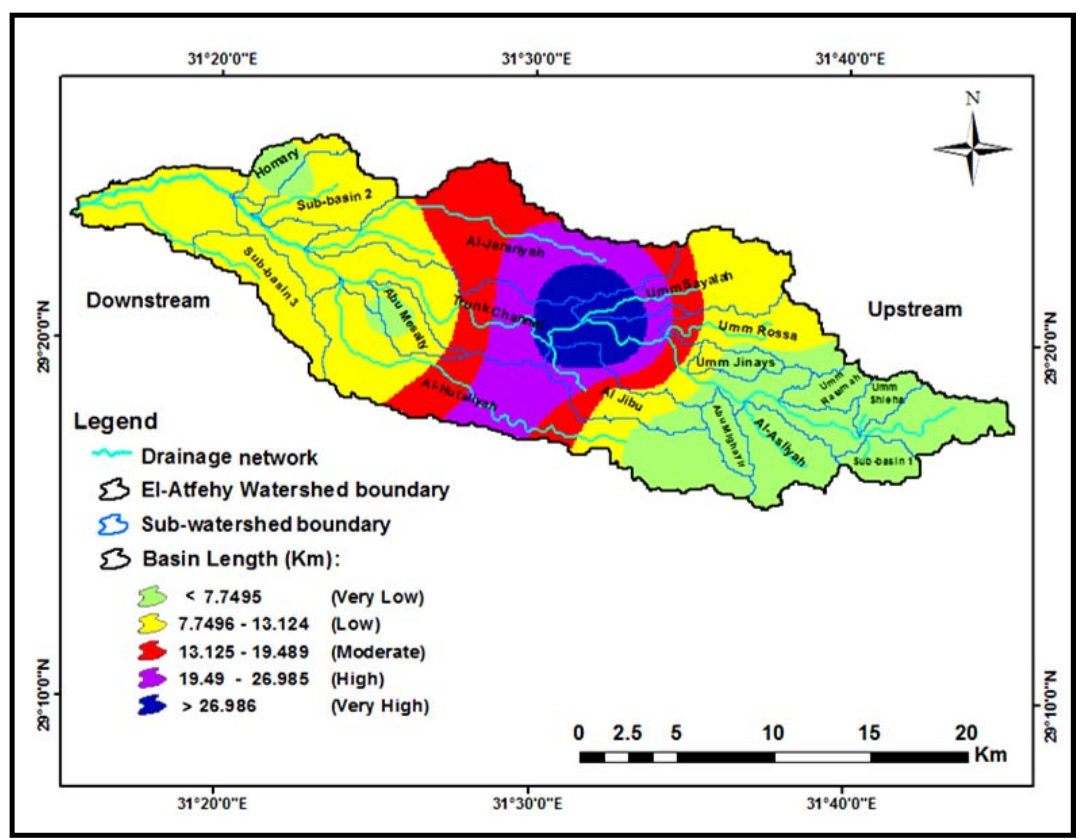

Fig. 10: The thematic layer of BL of El-Atfehy hydrographic basin.

\section{Basin Area (BA)}

The BA is the total area in square kilometers enclosed by the basin boundary (Horton, 1945). Basin area is important in controlling the basin runoff volume. Due to Morisawa, 1959 and Verstappen, 1983; the larger the size of the basin the greater the amount of rain it intercepts and the higher the peak discharge that result. The high positive correlation between BA and the discharge is related to that the BA is also highly correlated with some of the other hydro-morphometric features of the basin which influence runoff, such as BL, average OFD and the MFD (Gregory and Walling, 1976; Jain and Sinha, 2003) (Fig. 11).

Fig. 11: The thematic layer of BA of ElAtfehy hydrographic basin.

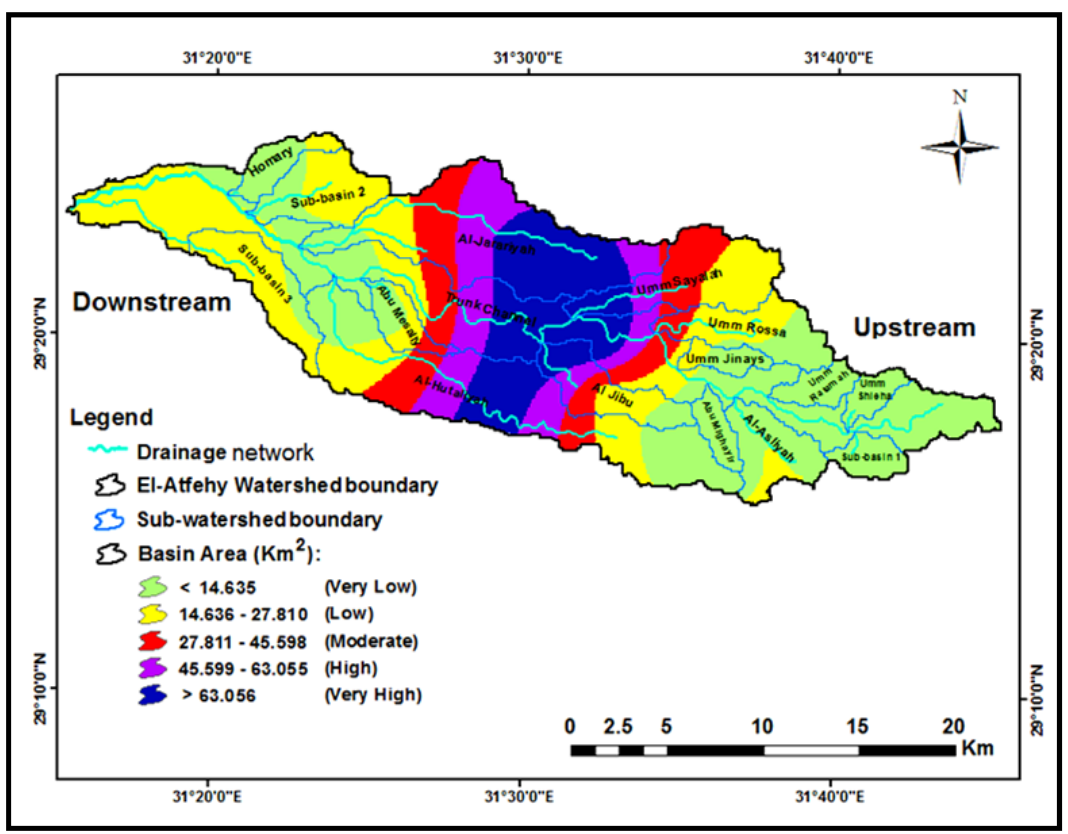

\section{Basin infiltration number (IF)}

The IF is the product of drainage density (Dd) and stream frequency (SF) (Faniran, 1968). The thematic layer show that the very high and high classes were concentrated in the western downstream parts of El- Atfehy hydrographic basin, which have low slope and high drainage density, where the very 
Hydrographical modelling for potentiality of water harvesting

low and low classes were concentrated in the eastern upstream part of El- Atfehy Hydrographic basin which have high slope and low drainage density (Fig.12).

$$
\mathrm{I}_{\mathrm{f}}=\mathrm{F}_{\mathrm{s}^{*}} \mathrm{D}_{\mathrm{d}}
$$

$F_{s}$ is the stream frequency $\left(\mathrm{Km}^{-2}\right)$ and $D_{d}$ is the drainage density $\left(\mathrm{Km}^{-1}\right)$

\section{Maximum Flow Distance (MFD)}

The MFD is the maximum length of the water's path in the drainage basin in kilometers. It is important in determining the RWH capability of a drainage basin, where the higher the MFD the higher the RWH possibilities, and vice versa (Fig. 13).

\section{Runoff Water Harvesting (RWH) potentiality modelling}

The eight thematic layers are ranked according to their contribution from the very high to very low. Two scenarios are proposed for weighting criteria; (1) Equal weights, and (2) Weights justified by the sensitivity.

\section{WSPM's Scenario (I) Equal Weighting of Criteria for Runoff Water Harvesting potentiality modelling}

The integrated criteria were proposed an equal weight of $12.5 \%$ with a summation of $100 \%$ for all data themes (Figure 14). RWH potentiality mapping are classified descending from (I) to (V) respectively as: $100-80,80-60,60-40,40-20$ and 20-0\% (Table 4).

Fig. 12: The thematic layer of IF of El-Atfehy hydrographic basin.
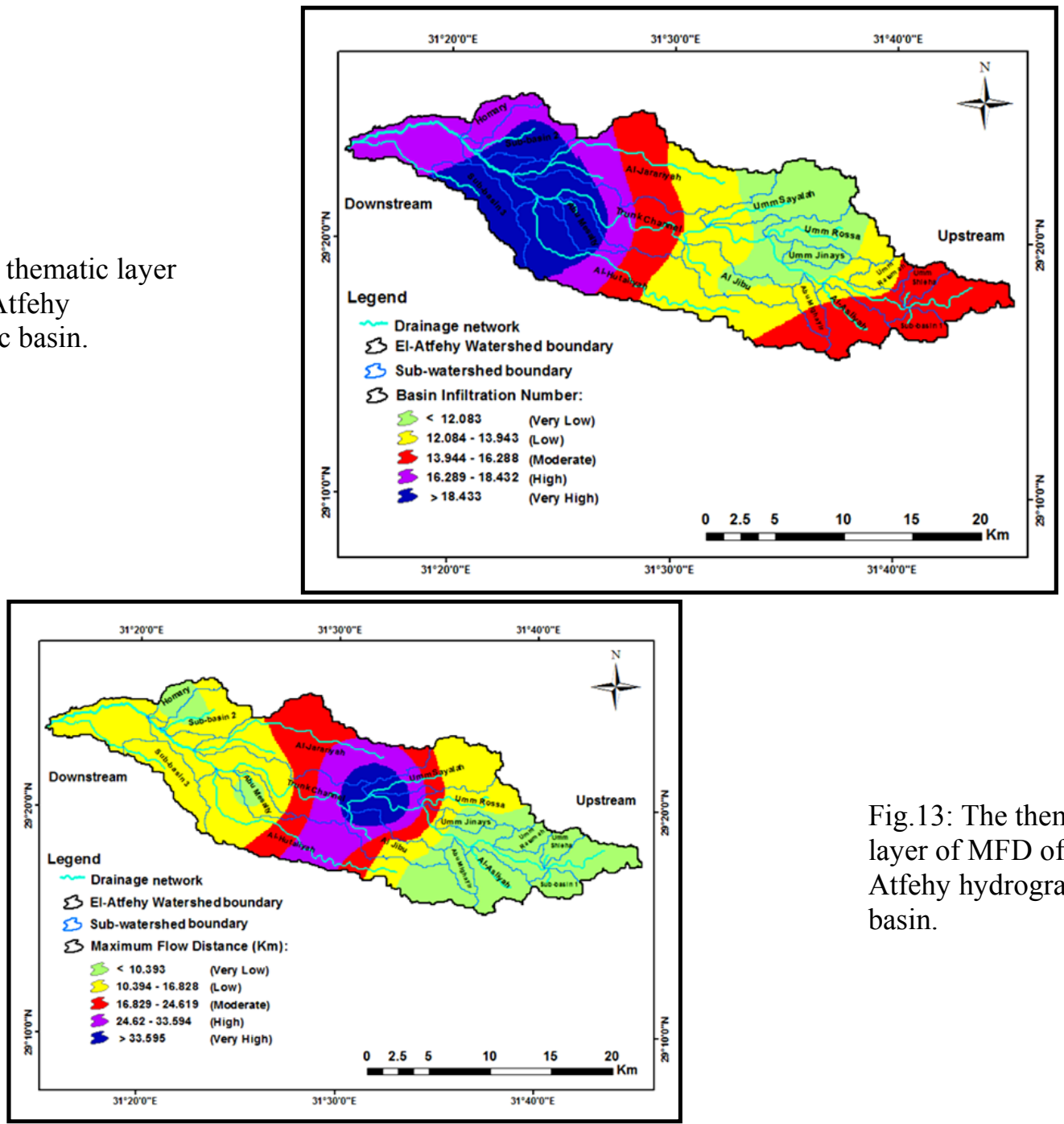

Fig. 13: The thematic layer of MFD of ElAtfehy hydrographic basin. 
Fig. 14: WSPM's Scenario (I) map showing the potential areas for the RWH of El-Atfehy hydrographic basin

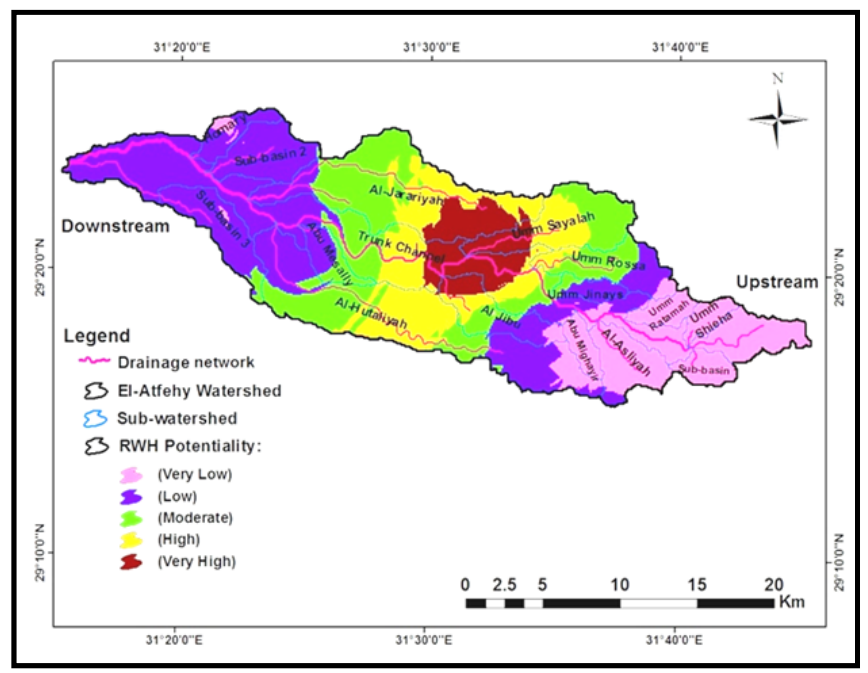

\section{WSPM's Scenario (II) Justified Weights by the Sensitivity Analysis for Runoff Water Harvesting} potentiality modelling:

Van Griensven et al., 2006 performed the sensitivity analysis to justify the weights of the decisive WSPM's criteria with (MCDSS) techniques for optimum RWH potential areas in the basin. It is performed through the following alternative procedures:

a. The WSPM's eight thematic layers or criteria are assumed to have the same weights $(12.5 \%$ equal effect) in the RWH potentiality mapping.

b. Seven parameters had been kept with equal weights of $10 \%$, while assigning only one parameter with the remaining $30 \%$. The results of the new weights have inputted to another run for the WSPM model as: overland flow distance $(9.55 \%)$, volume of runoff (5.520\%), basin slope (13.51\%), drainage density $(22.16 \%)$, basin length $(10.328 \%)$, basin area $(0.1212 \%)$, basin infiltration number $(31.932 \%)$, and maximum flow distance $(6.855 \%)$. The WSPM output map with five classes ranging from very low to very high potentiality was obtained (Fig. 15). The spatial distribution of these classes relative to the total studied area was: $86.9268 \mathrm{Km}^{2}$ for the very low, $81.10986 \mathrm{Km}^{2}$ for the low, $51.32596 \mathrm{Km}^{2}$ for the moderate, $120.729 \mathrm{Km}^{2}$ for the high, and $81.28389 \mathrm{Km}^{2}$ for the very high potentiality for the RWH (Table 5).

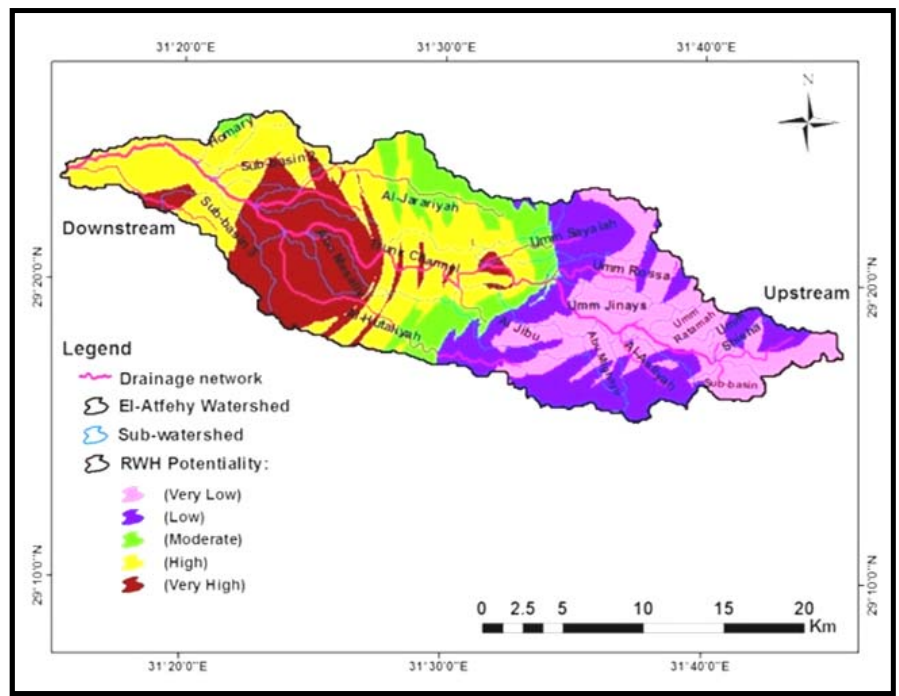

Fig. 15: WSPM map (Based on sensitivity results) showing the potential areas for RWH in El- Atfehy hydrographic basin. 
Hydrographical modelling for potentiality of water harvesting

\section{Water/Land use Probability modelling}

Four spatially integrating thematic layers representing the most decisive hydrographic and hydrogeological criteria for determining Water/Land use potentiality are used as inputs for the weighted spatial probability model (WSPM); they include: Volume of Runoff (VRF), basin Slope (BS), suitability of geological units (SGU), and groundwater prospectively units (GPU) (RIGW and NWRC, 1999). The suitability of geological units (SGU) for land use in El-Atfehy hydrographic basin is shown in (figure 16). The very high class (Class A) is represented by deposits and Nile Silt, whereas the high class (Class B) is represented by the undifferentiated Quaternary deposits. The third class (Class C) represents the sedimentary Kom el-Shelul Formation. Low suitability class (Class D) for water/land use is represented by Mokattam Group, and Beni Suef Fm.

Table 4: WSPM scenario I (equal weighting of criteria), ranks and degree of effectiveness of themes used for the RWH potentiality mapping of El-Atfehy hydrographic basin:

\begin{tabular}{|c|c|c|c|c|}
\hline Thematic layer (Criterion) & $\begin{array}{c}\text { RWH } \\
\text { potentiality class }\end{array}$ & $\begin{array}{c}\text { Average rate } \\
(\text { Rank }) \\
\left(\mathrm{R}_{\mathrm{c}}\right)\end{array}$ & Weight $\left(\mathrm{W}_{\mathrm{c}}\right)$ & $\begin{array}{c}\text { Degree of } \\
\text { Effectiveness (E) } \\
E=W_{c} \times R_{c}\end{array}$ \\
\hline Volume of Runoff (VRF) & $\begin{array}{l}\text { I (Very high) } \\
\text { II (High) } \\
\text { III (Moderate) } \\
\text { IV (Low) } \\
\text { V (Very low) }\end{array}$ & $\begin{array}{l}0.9 \\
0.7 \\
0.5 \\
0.3 \\
0.1\end{array}$ & 12.5 & $\begin{array}{l}11.25 \\
8.75 \\
6.25 \\
3.75 \\
1.25\end{array}$ \\
\hline $\begin{array}{l}\text { Average Overland Flow } \\
\text { Distance (OFD) }\end{array}$ & $\begin{array}{l}\text { I (Very high) } \\
\text { II (High) } \\
\text { III (Moderate) } \\
\text { IV (Low) } \\
\text { V (Very low) }\end{array}$ & $\begin{array}{l}0.9 \\
0.7 \\
0.5 \\
0.3 \\
0.1\end{array}$ & 12.5 & $\begin{array}{l}11.25 \\
8.75 \\
6.25 \\
3.75 \\
1.25 \\
\end{array}$ \\
\hline $\begin{array}{l}\text { Maximum Flow } \\
\text { Distance (MFD) }\end{array}$ & $\begin{array}{l}\text { I (Very high) } \\
\text { II (High) } \\
\text { III (Moderate) } \\
\text { IV (Low) } \\
\text { V (Very low) }\end{array}$ & $\begin{array}{l}0.9 \\
0.7 \\
0.5 \\
0.3 \\
0.1\end{array}$ & 12.5 & $\begin{array}{l}11.25 \\
8.75 \\
6.25 \\
3.75 \\
1.25 \\
\end{array}$ \\
\hline $\begin{array}{l}\text { Basin } \\
\text { Infiltration number (IF) }\end{array}$ & $\begin{array}{l}\text { I (Very high) } \\
\text { II (High) } \\
\text { III (Moderate) } \\
\text { IV (Low) } \\
\text { V (Very low) }\end{array}$ & $\begin{array}{l}0.9 \\
0.7 \\
0.5 \\
0.3 \\
0.1\end{array}$ & 12.5 & $\begin{array}{l}11.25 \\
8.75 \\
6.25 \\
3.75 \\
1.25 \\
\end{array}$ \\
\hline $\begin{array}{l}\text { Drainage Density } \\
\text { (DF) }\end{array}$ & $\begin{array}{l}\text { I (Very high) } \\
\text { II (High) } \\
\text { III (Moderate) } \\
\text { IV (Low) } \\
\text { V (Very low) } \\
\text { V (Very low) }\end{array}$ & $\begin{array}{l}0.9 \\
0.7 \\
0.5 \\
0.3 \\
0.1\end{array}$ & 12.5 & $\begin{array}{l}11.25 \\
8.75 \\
6.25 \\
3.75 \\
1.25\end{array}$ \\
\hline Basin Area (BA) & $\begin{array}{l}\text { I (Very high) } \\
\text { II (High) } \\
\text { III (Moderate) } \\
\text { IV (Low) } \\
\text { V (Very low) }\end{array}$ & $\begin{array}{l}0.9 \\
0.7 \\
0.5 \\
0.3 \\
0.1\end{array}$ & 12.5 & $\begin{array}{l}11.25 \\
8.75 \\
6.25 \\
3.75 \\
1.25\end{array}$ \\
\hline $\begin{array}{l}\text { Basin Slope } \\
\text { (BS) }\end{array}$ & $\begin{array}{l}\text { I (Very high) } \\
\text { II (High) } \\
\text { III (Moderate) } \\
\text { IV (Low) } \\
\text { V (Very low) }\end{array}$ & $\begin{array}{l}0.9 \\
0.7 \\
0.5 \\
0.3 \\
0.1\end{array}$ & 12.5 & $\begin{array}{l}11.25 \\
8.75 \\
6.25 \\
3.75 \\
1.25\end{array}$ \\
\hline $\begin{array}{l}\text { Basin Length } \\
\text { (BL) }\end{array}$ & $\begin{array}{l}\text { I (Very high) } \\
\text { II (High) } \\
\text { III (Moderate) } \\
\text { IV (Low) } \\
\text { V (Very low) }\end{array}$ & $\begin{array}{l}0.9 \\
0.7 \\
0.5 \\
0.3 \\
0.1\end{array}$ & 12.5 & $\begin{array}{l}11.25 \\
8.75 \\
6.25 \\
3.75 \\
1.25\end{array}$ \\
\hline
\end{tabular}


Morsy, S. M. and Abdel Monaim N. A

Table 5: Areas of RWH potentiality classes in El-Atfehy hydrographic basin (based on the results of sensitivity analysis of WSPM Scenario II):

\begin{tabular}{|c|c|c|c|c|c|}
\hline \multicolumn{6}{|c|}{ WSPM's map for the RWH potentiality classification } \\
\hline "RWH Potentiality Class & Very low & Low & Moderate & High & Very high \\
\hline Area $(\mathrm{Km} 2)$ & 86.926 & 81.109 & 51.325 & 120.729 & 81.283 \\
\hline $\begin{array}{c}\text { Area\% relative to the total } \\
\text { hydrographic basin area } \\
\text { (Total hydrographic basin area: } \\
424.100 \mathrm{Km} 2 \text { ) }\end{array}$ & 20.629 & 19.248 & 12.18057 & 28.6511 & 19.2901 \\
\hline
\end{tabular}

According to the productivity of groundwater for land use; the groundwater units were classified into three classes ranging from low to high in (Figure 17). The high class (Class A) for the wadi fills deposits aquifer, the moderate class (Class B) represents the local and moderately to low productive aquifers with insignificant surface recharge and limited sub-surface recharge; the deeper highly productive aquifers are not excluded. The low class (Class C) for groundwater productivity represents the extensive and moderately to low productive aquifers with paleo-karstified features containing fossil water, essentially with no surface recharge, but locally sub-surface recharge from adjacent aquifers may occur. Two scenarios are proposed for weighting criteria; (1) Equal Weighting of Criteria and (2) Justified Weights by the Sensitivity Analysis for Water/Landuse probability modeling.

Fig.16: SGU thematic layer used in the WSPM for water/land use potentiality mapping of El-Atfehy hydrographic basin
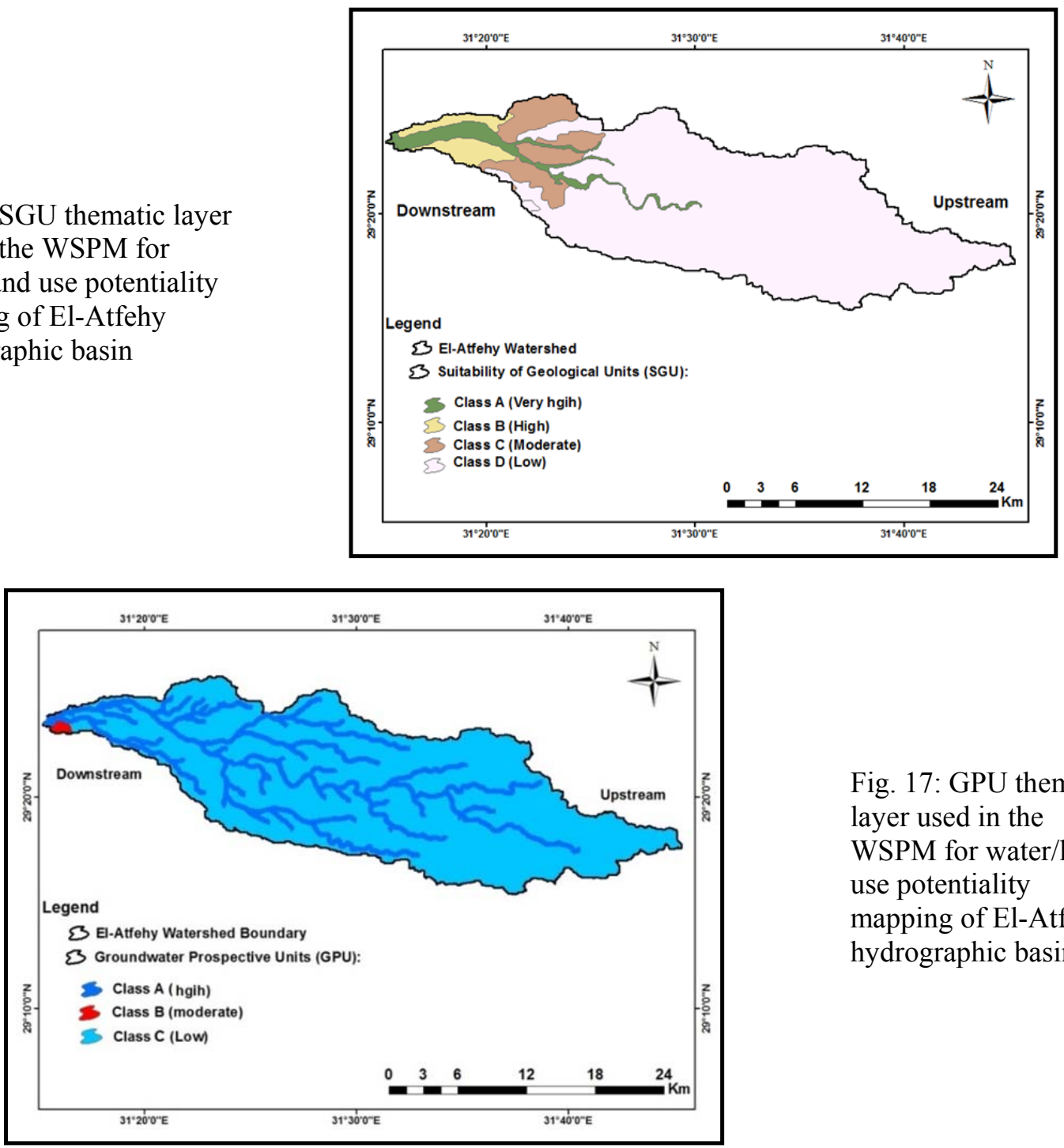

Fig. 17: GPU thematic layer used in the WSPM for water/land use potentiality mapping of El-Atfehy hydrographic basin. 
Hydrographical modelling for potentiality of water harvesting

\section{WSPM's Scenario (I) Equal Weighting of Criteria for water/land use probability modeling}

The four criteria are proposed to have the same contribution in the water/landuse mapping. An output map with several classes indicating the categories of water/land use potentiality (i.e. very high, high, moderate, low and very low) is obtained, table (6) and (Fig. 18). The (VRF) criterion works positively while (BS) criterion works negatively in the water/land use potentiality mapping. The other criteria work separately according to their specific contribution in land use capability determination.

Fig. 18: WSPM's scenario (I) map showing the potential areas for water/land use in El-Atfehy hydrographic basin.

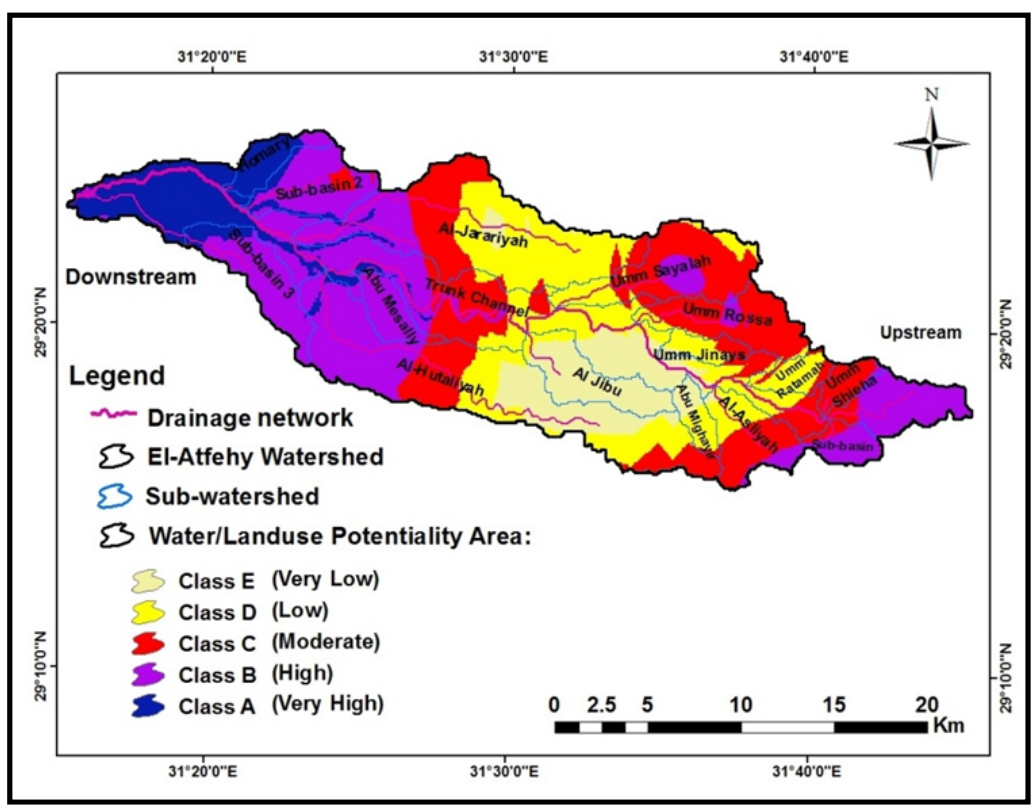

Table 6: Areas of water/land use classes for El-Atfehy hydrographic basin (equal criteria weighting)

\begin{tabular}{|c|c|c|c||c||c|}
\hline \multicolumn{5}{|c|}{ Areas of Water/Landuse Potentiality Classes } \\
\hline \hline Potentiality Class & Very Low & Low & Moderate & High & Very High \\
\hline \hline Area $\left(\mathrm{Km}^{2}\right)$ & 50.280 & 94.023 & 110.74 & 120.2 & 44.773 \\
\hline $\begin{array}{c}\text { Area \% relative to the total hydrographic } \\
\text { basin area } \\
\text { Total hydrographic basin area: } 424.100 \mathrm{Km}^{2}\end{array}$ & 11.969 & 22.383 & 26.362 & 28.62 & 10.658 \\
\hline \hline
\end{tabular}

\section{WSPM's Scenario (II) (Justified Weights by the Sensitivity Analysis) forWater/Landuse probability modelling}

In the WSPM's scenario (II), the sensitivity analysis (Van Griensven et al., 2006; Saisana et al., 2005) is applied to justify the weights of criteria used in the WSPM to obtain optimum water/Land use potential areas in El- Atfehy Hydrographic basin. The WSPM's sensitivity analysis for the determination of water/land use potentiality was performed through alternative steps as follows (Van Griensven et al., 2006):

1. Propose the WSPM's four thematic layers have the same contribution in the water/land use potentiality mapping. In this scenario, all criteria are assigned a weight of $25 \%$.

2. Determine the water/Land use potentiality by taking three parameters with an equal weight of $20 \%$, and only one parameter with $40 \%$. Subsequently, the sensitivity analysis is carried out using the variancebased method; the ANOVA (ANalysis Of VAriance), which aims to assess the effect of each criterion's variation on the bulk result of the WSPM output map. The effect of each model's criterion is calculated by comparing its effect on the summation of classes that have the High and Very High water/land use potentiality, this criterion was assigned a weight value of $40 \%$ compared to the first model's scenario of equal weights (Van Griensven et al., 2006). Table (7) represents a summation of all variance ratios of the high-very high potentiality classes for water/Land use in scenario (II) and their areas in scenario (I) is $28.8075 \%$. 
Morsy, S. M. and Abdel Monaim N. A

3. Based on the justified weight of each thematic layer, a new arithmetic overlay built in the ArcGIS $10.1(C$ within the Spatial Analyst Model Builder was carried out. To perform the WSPM, the new justified weights were used, i.e. VRF (23.452\%), BS (0.5268\%), SGU (76.020\%) and GPU (2.103\%). The WSPM output map with five classes from very low to very high potentiality for water/land use is obtained. The spatial areal distribution of these classes relative to the total hydrographic basin area is: $28.814 \%$ for the very low, $23.54 \%$ for the low, $29.96 \%$ for the moderate, $8.956 \%$ for the high, and $8.721 \%$ for the very high potentiality for the water/Land use (Figure 19).

Accordingly, the justified weight of each criterion was determined by dividing the variance ratio by the summation of all variance ratios.

Table 7: Variance ratios and justified weights of the WSPM's criteria used in the water/land use potentiality mapping for El-Atfehy hydrographic basin.

\begin{tabular}{|c|c||c||c||c|}
\hline \hline WSPM Criterion & BS & SGU & GPU & VRF \\
\hline Variance ratio \% & 0.1517 & 21.899 & 6.059 & 6.756 \\
\hline \hline Justified weight \% & 0.5268 & 76.020 & 2.103 & 23.452 \\
\hline
\end{tabular}

\section{Water/Landuse Master Plan of El-Atfehy hydrographic basin}

The most promising areas for water/Land use are the regions which were encompassed by the very high and high classes. These promising regions have a total area of about $74.180 \mathrm{~km} 2$, which constitutes about $17.659 \%$ of the total hydrographic basin area. These promising regions were subsequently sub divided into four priority areas according to their relative location to the planned RWH systems and the constructed or proposed utilities (i.e. dams, cisterns or groundwater wells) (Figure 20 \& Table 8).

Fig. 19: WSPM's scenario II map (justified by the sensitivity analysis) for water/land use in ElAtfehy hydrographic basin showing the potential areas

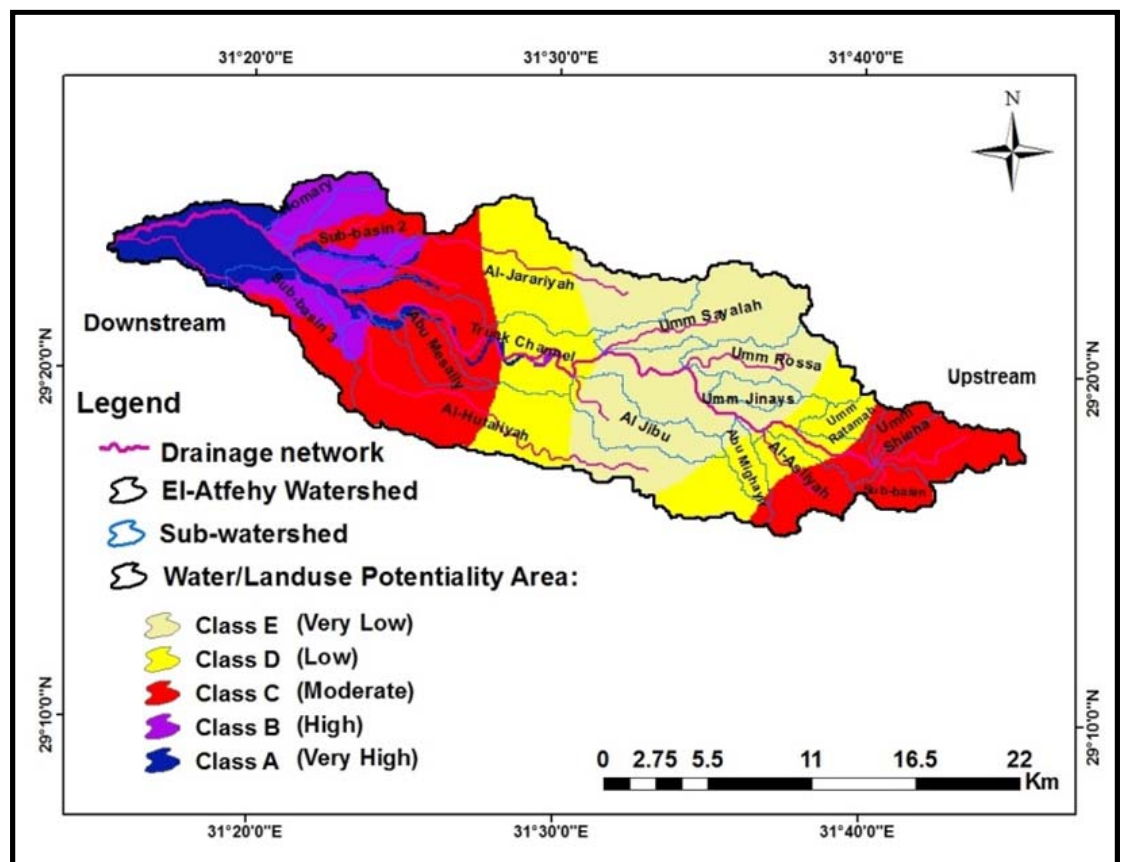

Table 8: Areas of water/Landuse master plan with their relative \% to the total area of El-Atfehy hydrographic basin.

\begin{tabular}{|c||c||c|}
\hline \hline Priority Area & Area $(\mathrm{km} 2)$ & $\begin{array}{c}\text { Area \% relative to the total } \\
\text { hydrographic basin area }\end{array}$ \\
\hline \hline First & 35.650 & 8.4868 \\
\hline Second & 0.8605 & 0.2048 \\
\hline Third & 0.9864 & 0.2348 \\
\hline \hline Fourth & 36.682 & 8.7326 \\
\hline
\end{tabular}




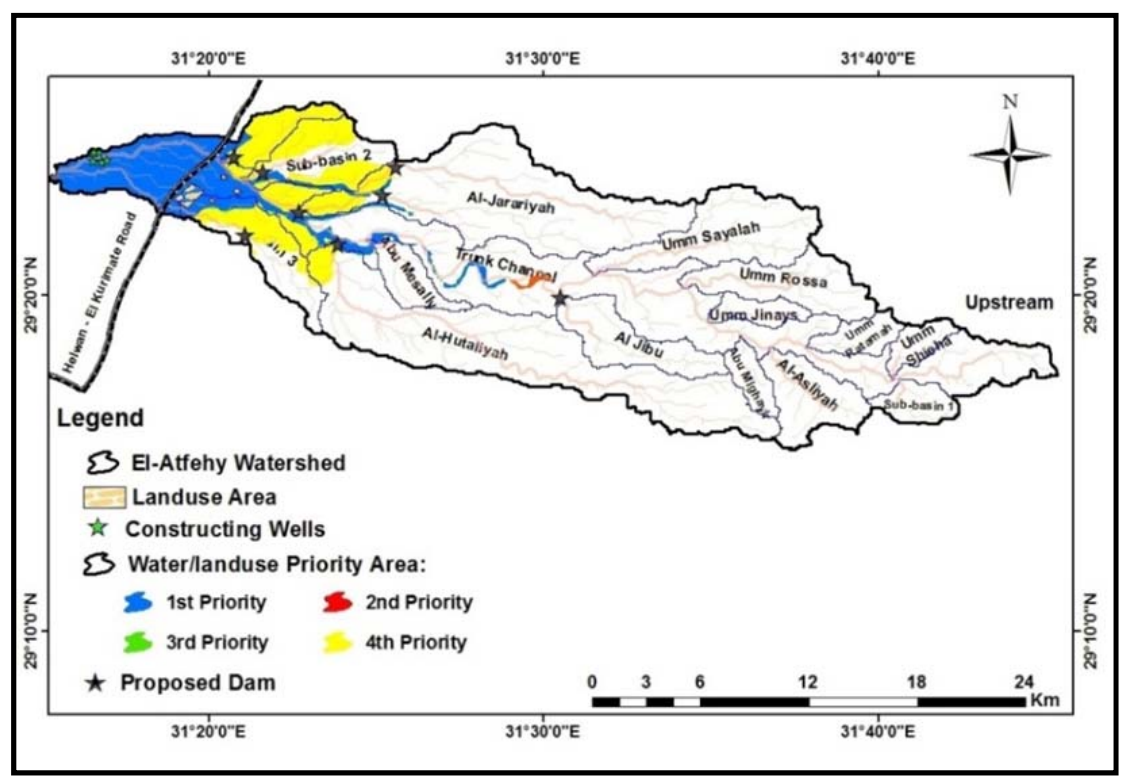

Fig. 20: Water/Land Use Master Plan of El-Atfehy hydrographic basin

The first priority region encounters an area of $35.650 \mathrm{~km}^{2}$, which represents $8.4868 \%$ of the total hydrographic basin area. This region occurs within the area of very high potentiality for water/land use (the Blue-colored area), which comprises in its vicinity: the most reliable geological formations (deposits), and proposed dams. The required surface water supply for the development of this region will be from the stored harvested water upstream the proposed dams. In conjunction, shallow groundwater aquifers and water wells, which will be recharged naturally by downward percolation in the vicinity of dams' lakes, will provide a supplemental source of water for irrigation and domestic uses during the rainless seasons. The water residence time upstream the proposed dams varies from four to six months.

The second priority region (red) with an area of $0.8605 \mathrm{~km}^{2}$, which represent $0.2048 \%$ of the total hydrographic basin area, will depend mainly on the groundwater in conjunction with the harvested surface runoff water, especially at the middle part of the hydrographic basin. This developmental region occurs within the area of high potentiality class for water/land use, where it also comprises in its vicinity the deposits of high reliability in land use planning.

However, for future development, the third and fourth priority regions have a total area of $37.669 \mathrm{~km}^{2}$, which are representing the remaining areas of the very high and high potentiality classes for water/land use planning.

\section{Surface Storage Plans in El-Atfehy hydrographic Basin}

The hydrographic basin management plan for El-Atfehy was proposed to increase the storage capacity of the basin. This could be performed by the construction of eight small dams in the Homary, Sub-basin 2, Sub-basin 3, Al-Hutaliyah, Al-Jarariyah, Al Jibu, and the Main Channel sub-basins, at the selected locations are shown (figure 21 and Table 9) presents the geographic locations of proposed dams in ElAtfehy Hydrographic basin with their storage capacities.

Table 9: Coordinates and storage capacity of the proposed storage dams in El-Atfehy hydrographic basin:

\begin{tabular}{|c|c|c|c|}
\hline Dam Name & Long & Lat & Storage capacity $\mathrm{m}^{3}$ \\
\hline Al Jibu Dam & $313030.34 \mathrm{E}$ & $291955.90 \mathrm{~N}$ & 5,724 \\
\hline Al Hutaliyah Dam & $312350.99 \mathrm{E}$ & $292130.23 \mathrm{~N}$ & $11,907.9$ \\
\hline Main channel Dam & $312240.73 \mathrm{E}$ & $292228.14 \mathrm{~N}$ & $28,598.4$ \\
\hline Dam 1 & $312104.91 \mathrm{E}$ & $292146.76 \mathrm{~N}$ & $9,498.6$ \\
\hline Dam 2 & $312136.28 \mathrm{E}$ & $292338.48 \mathrm{~N}$ & $9,755.1$ \\
\hline Al Jarariyah Dam 1 & $312534.40 \mathrm{E}$ & $292347.54 \mathrm{~N}$ & $5,646.15$ \\
\hline Al Jarariyah Dam 2 & $312511.04 \mathrm{E}$ & $292257.78 \mathrm{~N}$ & $5,646.15$ \\
\hline Homaray Dam & $312044.57 \mathrm{E}$ & $292405.68 \mathrm{~N}$ & $32,957.1$ \\
\hline
\end{tabular}


Fig. 21: Location map of proposed storage dams in El-Atfehy hydrographic basin

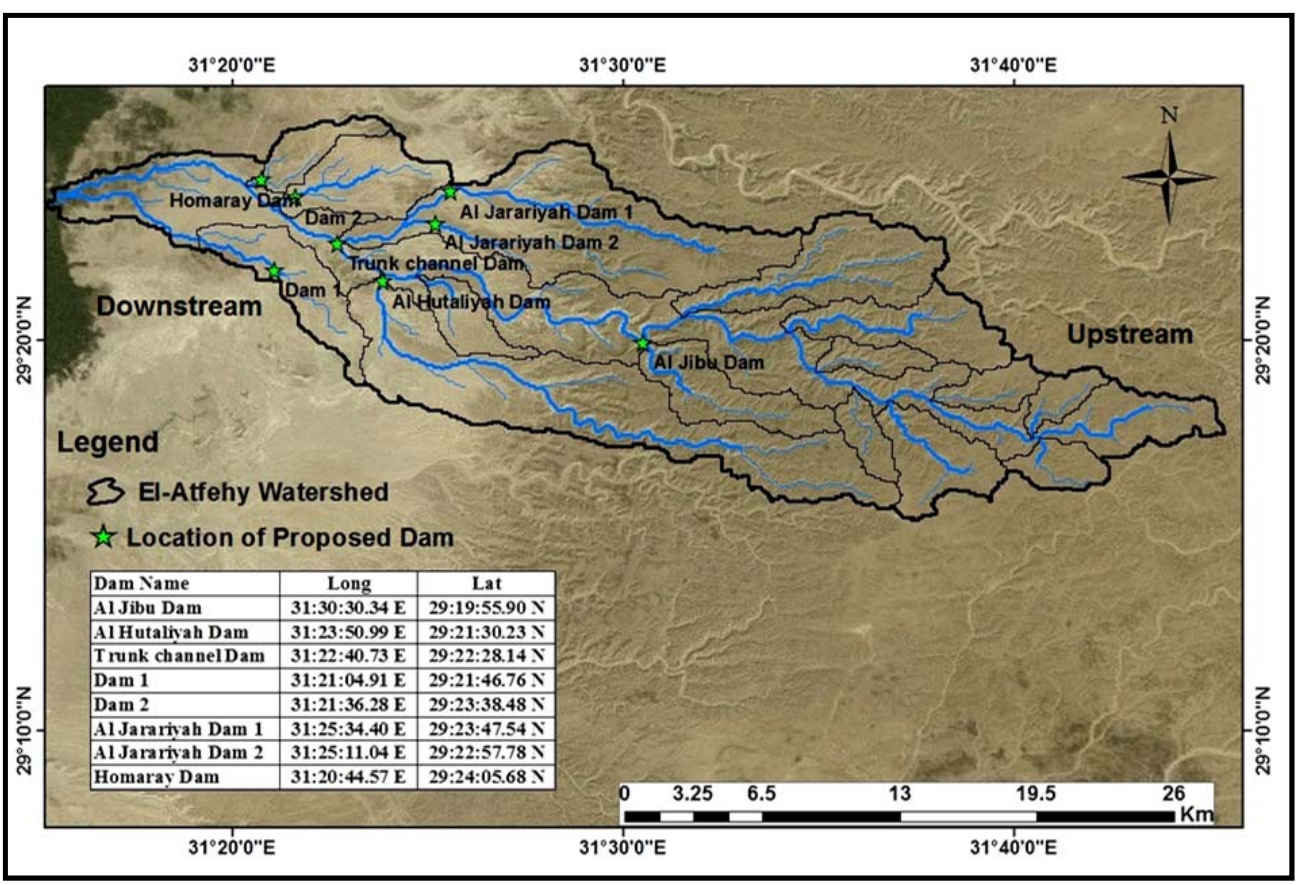

\section{CONCLUSION}

An integration of geographic information system (GIS); remote sensing (RS) and watershed (WMS) modelling techniques; along with geomorphological and field studies was applied to achieve a proper implementation of Runoff Water Harvesting (RWH) potentiality as well as Water/Landuse master plan of Wadi El Atfehy hydrographic basin north eastern desert; Egypt. Two weighted spatial probability models' scenarios (WSPMs) were generated for determining the RWH potentialities of El-Atfehy hydrographic basin. The output map revealed five RWH potentiality classes ranging from very low $(19.248 \%$ of the total hydrographic basin) to very high $(28.65 \%$ of the total hydrographic basin area) runoff potentiality. The spatial distribution of these classes relative to the total studied area is: $86.9268 \mathrm{Km}^{2}$ for the very low, $81.10986 \mathrm{Km}^{2}$ for the low, $51.32596 \mathrm{Km}^{2}$ for the moderate, $120.729 \mathrm{Km}^{2}$ for the high, and $81.28389 \mathrm{Km}^{2}$ for the very high potentiality for the RWH. The water/Landuse potentiality mapping of El-Atfehy hydrographic basin is determined by spatially integrating four thematic layers, which represent the most decisive hydrographic and hydro-geological criteria for determining the Water/Land use potentiality. The major area of El-Atfehy hydrographic basin is categorized as of moderate potential for the water/Land use, which constitutes $29.962 \%$ of the total watershed area, especially in the western and eastern central parts. The water/land use potentiality is noticeably decreasing to low and very low $(23.545 \%$ and $28.814 \%$, respectively) toward the middle parts of El-Atfehy hydrographic basin. The present study proposed a management plan for future development for El-Atfehy hydrographic basin; to increase the storage capacity of the basin. It suggests the construction of eight small dams in the Homary, Sub-basin 2, Subbasin 3, Al-Hutaliyah, Al-Jarariyah, Al Jibu, and the Main Channel sub-basin with storage capacities ranging from $32,957.1 \mathrm{~m}^{3}$ to $5,724 \mathrm{~m}^{3}$. The integration of geographic information system (GIS); remote sensing (RS) and watershed (WMS) modelling is an effective approach for sustainable development of water resources and could be applicable for similar regions in the world.

\section{REFERENCES}

Abdel Moneam, N. A., (2016): Hydrogeological study of water resources and flood control Management, Wadi El-Atfehy, Eastern Desert, Egypt, M. Sc. Thesis, Fac. Sci., Ain Shams Univ., 200p.

Aher, P. D., Adinarayana J. and Gorantiwar S. D., (2014): Quantification of morphometric characterization and prioritization for management planning in semi-arid tropics of India: A remote sensing and GIS approach. Journal of Hydrology, 511:850-860. 
Hydrographical modelling for potentiality of water harvesting

Aquaveo. http://www.aquaveo.com/)

Bapalu G. V., Sinha R., (2005): GIS in Flood Hazard Mapping: A Case Study of Kosi River Basin, India”. GIS@ Development. 1(13):13 (October 2005 http://www.gisdevelopment.net/application/ natural hazards/ floods/).

Conoco (Continental Oil Company), (1987): Geological Map of Egypt (Scale 1: 500,000). Conoco Inc. in Collaboration with Freie University at Berlin, ISBN 3-927541-09-5.

El Ghazawi M. M.; Korany E. A., Faiad B. J., (2001): Hydrogeological evaluation of the Quaternary aquifer in the Delta of Wadi El-Atfehy, Eastern Desert, Egypt. Ann. Geol Surv. Egypt 18(3), 883-900.

El Maghraby M., Masoud M. and Niyazi B., (2014): present paper search on Assessment of surface runoff in arid, data scarce regions; an approach applied in Al Hamd, Al Madinah Al Munawarah, Saudi Arabia. Life Science Journal, 11(4).271-289.

Elewa H.H., Qaddah A.A. and El-Feel A.A., (2012): Determining Potential Sites for Runoff Water Harvesting using Remote Sensing and Geographic Information Systems-Based Modeling in Sinai. American Journal of Environmental Sciences, Science Publications, USA, 8: 42-55.

Elewa H.H., Shohaib R.G., Qaddah A.A. and Nousir A. M., (2013): Determining Groundwater Protection zones for the Quaternary aquifer of northeastern Nile Delta using GIS-based vulnerability mapping. Environmental Earth Sciences, Springer Verlag, Heidelberg, Berlin, 68:313-331. DOI 10.1007/s12665-012-1740-x.

Faiad, B. J., (1996): MSc. thesis, Faculty of Science, Ain shams Univ., Hydrolgeological studies of the groundwater system in the Quaternary aquifer, El-Atfehy, Eastern Desert, Egypt.

Faniran, (1968): the index of drainage intensity - A provisional new drainage factor. Australian J. Sci, 31, 328-330.

Gregory, K. J. \& Walling, D. E., (1976): Drainage Basin Form and Process: A Geomorphological Approach, Edward Arnold, London, 456p.

Horton, R. E., (1932): Drainage basin characteristics: Trans. Am. Geophys. Union, 13, 350-361.

Horton, R.E., (1945): Erosional development of stream and their drainage basin. Hydrogeological approach to quantitative morphology. Bull.Geol. Soc. Am 56: 275-370.

Jain V. and Sinha R., (2003): Evaluation of Geomorphic control on flood hazard through geomorphic instantaneous Unit Hydrograph. Current Sci., 85: 26-32.

Korany, E. A., (1980): Peak-runoff calculations and preventing the risk of occasional flooding in Sannur drainage basin, Eastern Desert, Beni-suef governorate, Egypt. Proc. $5^{\text {th }}$ Inter. Congr. Statist. Comput. Sci., Social and Demogr. Res., Ain Shams Univ., Cairo, (29 March -3 April 1980), 505-534.

Korany, E. A., (1995):Hydrology and development of El-Atfehy, Eastern Desert, Egypt; 1st. Inter. Sci. Conf., Fac. Sci., Azhar Univ., Cairo, Egypt, (Extended Abstract, 3p. and 15 Fig.).

Korany, E.A., Soliman, M.M. and Faiad, B. J., (1997): Modeling of the hydrogeologic Response of the of the Quaternary aquifer system in the delta of El-Atfehy, Eastern Desert, Egypt. An Assessment approach for development of groundwater resources: Ain Shams Sci. Bull., 35, 89-110.

Leopold L. B. and Maddock T., (1953): The hydraulic geometry of stream channels and some physiographic implications: U.S. Geol. Survey Prof. Paper 252, 52p.

Malczewski J., (1996): A GIS-based approach to multiple criteria group decision-making. Inter. J. Geographic Information Systems, 10: 955-971.

Malczewski J., (2006): GIS-based multi criteria decision analysis: a survey of the literature. International Journal of Geographic Information Systems, 20: 703-726.

Mansour, H. H. Philobbos, E. R. Khalifa, H. and Abdu, F. H., 1982. Contribution to the geology of the area east and northeast of Beni-suef, Nile Valley, Egypt. Qatar Univ. Sci. Bull, 2, 258-279.

Moneim, A. A., (2005): Overview of the geomorphological and hydrogeological characteristics of the Eastern Desert of Egypt. Hydrogeol. J. 13(2), 416-425.

Montgomery, D. R., Dietrich W. E., (1989): Source areas, drainage density, and channel initiation. Water Res. Res., 34: 1907-1918.

Morisawa M.E., (1959): Relation of morphometric properties to runoff in the Little Mill Creek, Ohio Drainage Basin, (Columbia University, Dept. of Geol.) Technical Report, 17, office of Naval Res., Project NR 389-042. 
Morsy, S. M., (2016): Drainage Patterns network and hydrogeological functions, Wadi El Atfehy hdrographic basin, Eastern Desert, Egypt, Egy. J. Pure \& Applied Sci., 54(2):45-56.

NWRC (National Water Research Center), (2003): National Water Quality and Availiability Management Project (NAWQAM), National Water Research Center, Cairo, Egypt.

RIGW (Research Institute for Groundwater) and NWRC (National Water Research Center) (1999): Hydrogeological map of Egypt scale 1: 2000,000.

Said, R., (1962): The Geology of Egypt. Elsevier, Amesterdam, 377p.

Said, R., (1971): Explanatory notes to accompany the geological map of Egypt: Geo. Surv. Egypt, 56, $123 \mathrm{p}$.

Said, R., (1990): The Geology of Egypt: A. A. Blakema, Rotterdam, 734 p.

Saisana A., Saltelli A. and Tarantola S., 2005. Uncertainty and sensitivity analysis techniques as tools for the quality assessment of composite indicators. J. R. Stat. Soc., 168: 307-323.

Saleh A. S., (1990): Geomorphological Effect of a Torrential Flood in El-Atfehy, the Eastern Desert of Egypt. B.S. de Geo. E. Tom LX-III, 99-127.

Soil Conservation Service (1972): National Engineering Handbook, Section 4, U.S. Department of Agriculture, Washington, D.C. NEH Notice 4-102

Soil Conservation Service (1975): Urban Hydrology for Small Watersheds., U.S. Department of Agriculture, Washington, D.C. Technical Release No.55, 16p.

Subba Rao N., (2006): Groundwater potential index in a crystalline terrain using remote sensing data. Environ Geol, 50:1067-1076. DOI 10.1007/s00254-006-0280-7.

United States Department of Agriculture. (1986): Urban hydrology for small watersheds (PDF). Natural Resources Conservation Service, Conservation Engineering Division. 210-VI-TR-55, $2^{\text {nd }}$ ed.

Van Griensven A., Meixner T., Grunwald S., Bishop T., Diluzio M. and Srinivasan R., (2006): A global sensitivity analysis tool for the parameters of multi-variable catchment models. Journal of Hydrology 324: 10-23. doi: 10.1016/j.jhydrol.2005.09.008

Verstappen H., (1983):The applied geomorphology, International Institute for Aerial Survey and Earth Science (I.T.C.), Enschede, Netherlands, Amsterdam, Oxford, New York. 
Hydrographical modelling for potentiality of water harvesting

نمذجة هيدروجغرفية لأمكانات حصاد المياه وإستخدام المياه والأراضى ، وادى الأطفيحي ، الصحراء الشرقية ، مصر

\section{سماح محمود مرسى سعد ونرمين اشرف عبد المنعم}

قسم الجيولوجيا - كلية العلوم- -جامعة عين شمس و الهيئة القومية للأستثعار عن بعد وعلوم الفضاء

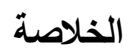

تم عمل خرائط إمكانات حصاد المياه لوادي الأطفيحي بإستخدام برنامج نظم المعلومات الجغرافية عن طريق دمج مكاني

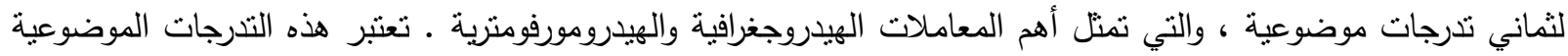

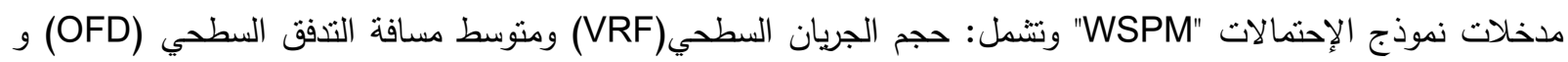
إنحدار سطح حوض التصريف (BS) وكثافة الصرف (Dd) وطول حوض التصريف (Bd) ومساحة حوض التصريف (BA)

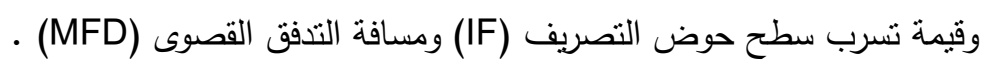

من خريطة WSPM يمكن أن نخلص إلى أن المنطقة الرئيسية من وادى الأطفيحي نتمثل فى الفئة عالية وعالية جداً فى الى

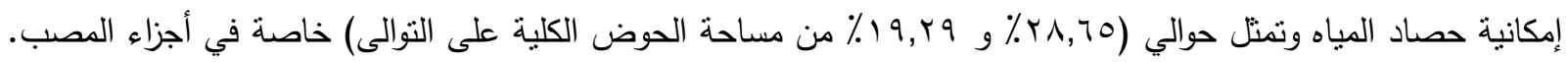

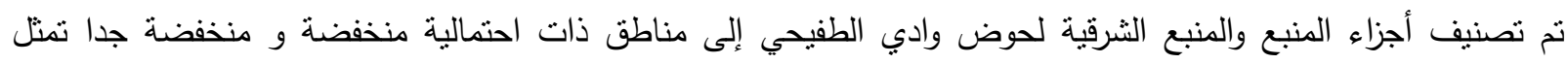

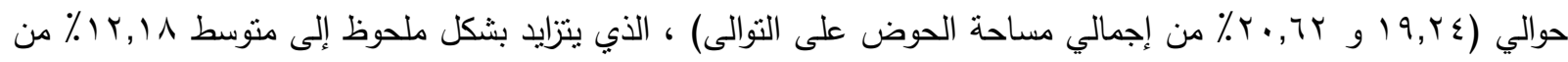

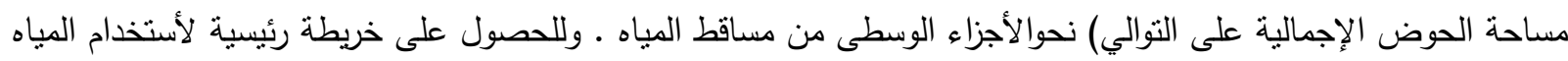

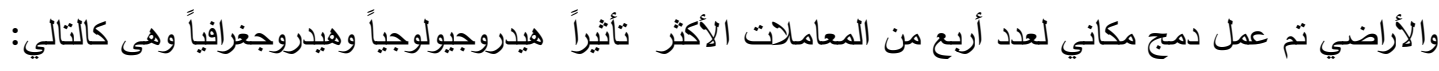
• حجم الجريان السطحي (VRF) • إنحدار سطح الحوض (BS) • ملاعمة الوحدات الجيولوجية (SGU) • المياه الجوفية

في السيناريو الثاني من الخريطة بمكن أن نخلص إلى أن المنطقة الرئيسية من وادي الأطفيحي تتميز بجهد منوسط من

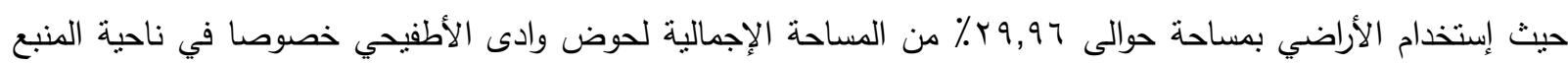

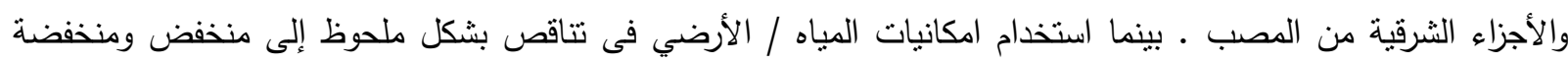

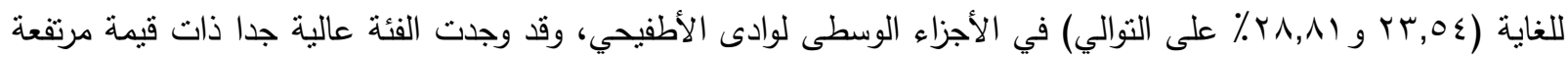

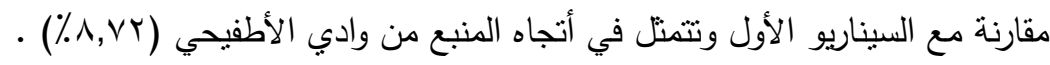
المساحات الواعدة في خطة استخدام المياه والأراضي هي المناطق التي تتنملها الدرجات العالية جدا والعالية. هذه المناطق

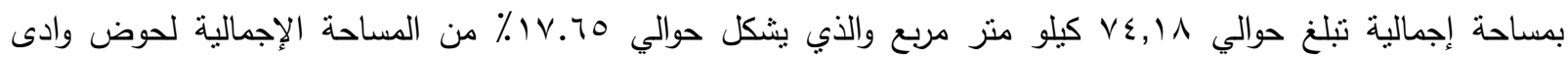

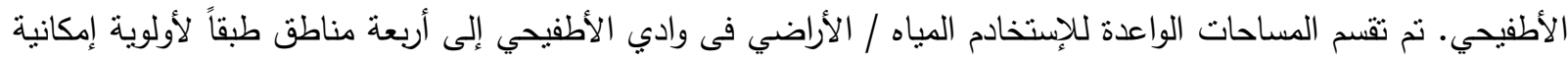

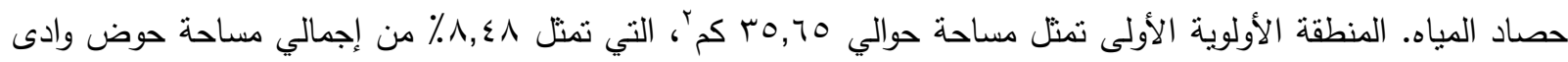

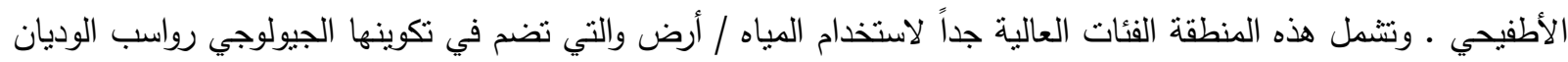

